\title{
Regulatory Region SNP
}

National Cancer Institute

\section{Source}

National Cancer Institute. Regulatory Region SNP. NCI Thesaurus. Code C41010.

Single Nucleotide Polymorphism in Regulatory Sequences (Regulatory Region SNP)

consists of a variation at an appreciable frequency between individuals of a single

interbreeding population of a single nucleotide, due to base substitution, at an equivalent

location within a gene region that is involved in the regulation of genetic processes, such as transcription and replication. 